\title{
PENENTUAN UKURAN OPTIMAL PETAK UKUR PERMANEN UNTUK HUTAN TANAMAN AGATHIS (Agathis loranthifolia Salisb.)
}

\author{
Determination of Permanent Sample Plot Size \\ for Agathis loranthifolia Salisb. Plantation Forest \\ Harbagung \\ Pusat Litbang Hutan Tanaman \\ Kampus Balitbang Kehutanan, JI. Gunung Batu No. 5, Bogor \\ Telp. (0251) 863 238, Fax. (0251) 7520005
}

Naskah masuk : 24 April 2008 ; Naskah diterima : 16 Februari 2009

\begin{abstract}
Permanent Sample Plot (PSP) is a tool to collect accurate information on stand growth and yield data. Effort in obtaining such data, however, requires a lot of time and labor. A study on the smallest size of PSP which could represent the condition of the stand is, therefore, necessary. Five sample plots with size of $120 \mathrm{~m} \times 120 \mathrm{~m}$ each were established for this study on Agathis loranthifolia Salisb. plantations located in Baturaden, Purwokerto District, Central Java Province. The results showed that the optimal size of PSP for monitoring the number of trees periodically was $100 \mathrm{~m} \times 100 \mathrm{~m}$. For monitoring diameter and stand height increment, the optimal size was $40 \mathrm{~m} \times 40 \mathrm{~m}$, set in the center of plot.
\end{abstract}

Key words: Agathis loranthifolia Salisb., plantation forest, permanent sample plot, PSP

\begin{abstract}
ABSTRAK
Petak Ukur Permanen (PUP) merupakan sarana pengumpulan data riap/pertumbuhan tegakan yang akurat, namun kegiatan pengumpulan data tersebut membutuhkan waktu yang lama dan tenaga yang besar. Sehubungan dengan itu perlu dilakukan kajian ukuran PUP terkecil yang representatif dapat mewakili kondisi tegakan. Lima petak contoh berukuran $120 \mathrm{~m}$ x $120 \mathrm{~m}$ pada hutan tanaman Agathis (Agathis loranthifolia Salisb.) di Baturaden, Kabupaten Purwokerto, Jawa Tengah, dijadikan bahan kajian ini. Hasil kajian menunjukkan bahwa ukuran optimal PUP untuk pemantauan dinamika jumlah pohon dari waktu ke waktu adalah petak/plot ukuran $100 \mathrm{~m} \times 100 \mathrm{~m}$. Pengukuran riap diameter dan tinggi tegakan dilakukan pada petak $40 \mathrm{~m}$ x $40 \mathrm{~m}$ yang diletakkan di tengah petak $100 \mathrm{~m} \times 100 \mathrm{~m}$.
\end{abstract}

\section{Kata kunci: Agathis loranthifolia Salisb., hutan tanaman, petak ukur permanen, PUP}

\section{PENDAHULUAN}

\section{A. Latar Belakang}

Penyusunan rencana pengelolaan hutan tanaman menuntut tersedianya berbagai data dan informasi kondisi tegakan, dan data riap atau pertumbuhan tegakan merupakan salah satu data pokok yang sangat penting dalam penyusunan rencana pengelolaan hutan tanaman. Data tersebut antara lain ditujukan untuk penentuan panjang daur dan jatah tebangan tahunan. 
Mengingat pentingnya informasi riap tegakan sebagai dasar penyusunan rencana pengelolaan hutan secara lestari, Menteri Kehutanan telah mengeluarkan Keputusan Nomor 237/Kpts-11/95 yang mewajibkan setiap unit pengusahaan hutan produksi (termasuk pengelola hutan tanaman) untuk membangun dan melakukan pengukuran PUP secara periodik untuk memantau riap tegakan di kawasan hutan yang bersangkutan.

Data riap tegakan dapat dikumpulkan dengan melakukan inventarisasi tegakan. Ada 2 macam kegiatan inventarisasi, yaitu inventarisasi statis (static inventory) dan inventarisasi dinamis (dynamic inventory) (Vanclay, 1994). Inventarisasi statis ditujukan untuk mengetahui potensi tegakan pada suatu waktu tertentu dilakukan dengan menggunakan petak ukur temporer - PUT (temporary sample plot $T S P$ ), sedangkan inventarisasi dinamis yang ditujukan untuk mengumpulkan informasi pertumbuhan tegakan dilakukan dengan pembuatan dan pengukuran petak ukur permanen - PUP (permanent sample plot-PSP).

PUP merupakan sarana penting dalam pengumpulan data lapangan untuk mengetahui riap diameter dan volume serta dinamika struktur tegakan (Priyadi et al., 2006), dan data pertumbuhan yang dikumpulkan melalui pengukuran berulang (time series) PUP merupakan deret pertumbuhan nyata (Alder, 1980).

PUP adalah "miniatur" dari tegakan yang diwakilinya, sehingga dalam hal ini ukuran PUP sangat berperan terhadap representatif tidaknya PUP tersebut mencerminkan kondisi tegakan. Semakin besar ukuran, maka PUP akan semakin mampu menampung keragaman parameter tegakan yang diwakilinya, namun permasalahannya semakin besar ukuran PUP akan semakin besar waktu dan tenaga yang diperlukan untuk pembuatan dan pengukurannya. Sehubungan dengan itu, kajian-kajian perlu dilakukan untuk memperoleh informasi cara pembuatan dan pengukuran PUP hutan tanaman yang efektif dan efisien.

\section{B. Tujuan Penelitian}

Penelitian ini bertujuan untuk menemukan ukuran optimal PUP hutan tanaman Agathis loranthifolia Salisb., dalam arti luas areal terkecil tetapi mampu menampung keragaman semua parameter kondisi tegakan.

\section{METODE PENELITIAN}

\section{A. Pendekatan Masalah}

Istilah "permanen" dalam rangkaian kata "Petak Ukur Permanen" (PUP) mengandung arti bahwa petak ukur tersebut bersifat tetap, diukur periodik terus menerus sejak PUP dibuat/ditetapkan sampai tegakan di dalamnya mencapai umur tua atau daur.

Kondisi tegakan berumur tua merupakan "retriksi" utama yang harus dipertimbangkan dalam pelaksanaan penelitian, karena dari tegakan muda menuju tegakan tua pada suatu tegakan hutan tanaman akan mengalami serangkaian proses, yaitu adanya kematian dan atau karena perlakuan penjarangan sehingga jumlah pohon semakin sedikit. Oleh karena itu, ukuran PUP yang cocok untuk tegakan tua pasti bisa menampung keragaman struktur tegakan muda, tetapi sebaliknya ukuran PUP yang cocok untuk tegakan muda belum tentu cocok setelah tegakan di dalamnya menjadi tua. Berdasar fenomena tersebut, maka analisis ukuran terkecil dalam pembuatan PUP cukup dibatasi hanya pada tegakan tua sebagai obyek kajian.

Kegiatan inventarisasi pada berbagai ukuran atau luas PUP hutan tanaman biasanya mencakup data umur tegakan, diameter dan tinggi setiap pohon, dan melalui perhitungan dan penjabaran sederhana dapat diperoleh informasi mengenai gambaran kondisi tegakan yang diwakili oleh PUP yang 
bersangkutan, meliputi jumlah pohon tiap hektar, diameter tegakan, luas bidang dasar tiap hektar, volume tegakan, tinggi tegakan, dan peninggi.

Penjabaran untuk memperoleh semua informasi parameter tersebut secara garis besar adalah sebagai berikut:

- data jumlah pohon dalam PUP dan luas PUP dapat menginformasikan ${ }^{1)}$ jumlah pohon tiap hektar;

- data diameter setiap pohon dan jumlah pohon dalam PUP menginformasikan ${ }^{2)}$ diameter tegakan;

- data diameter setiap pohon menginformasikan luas bidang dasar dalam PUP, dan dengan faktor penimbang luas PUP dapa diperoleh informasi ${ }^{3}$ luas bidang dasar tiap hektar;

- data diameter dan tinggi setiap pohon menginformasikan volume tegakan dalam PUP, dan dengan faktor penimbang luas PUP dapat diperoleh informasi ${ }^{4}$ volume tegakan tiap hektar;

- data tinggi setiap pohon dan jumlah pohon dalam PUP menginformasikan ${ }^{5}$ tinggi tegakan;

- data tinggi setiap pohon menginformasikan ${ }^{6}$ peninggi tegakan yang dapat digunakan sebagai indikator kualitas tapak.

Informasi lain yang dapat diperoleh dari pengukuran PUP adalah gambaran struktur tegakan yang biasanya digambarkan dalam bentuk sebaran jumlah pohon menurut kelas diameter seperti bentuk Tabel 1.

Dalam Tabel 1 tampak bahwa susunan jumlah pohon menurut kelas diameter dapat "dikunci" dengan Peubah- $N$ bersama Peubah- $B$; atau dengan kata lain apabila dua populasi suatu jenis tegakan dalam luas areal yang sama mempunyai $N$ dan $B$ yang sama, maka kemungkinan besar sebaran diameter kedua tegakan tersebut adalah sama.

Tabel(Table) 1. Contoh bentuk tabel sebaran sebaran diameter tegakan (Example of table of stand diameters distribution)

\begin{tabular}{|c|c|c|c|}
\hline $\begin{array}{l}\text { Kelas diameter } \\
\text { (Diameter class) }\end{array}$ & $\begin{array}{l}\text { Nilai tengah } \\
\text { (Midpoint) }\end{array}$ & $\begin{array}{c}\text { Jumlah pohon } \\
\text { (Number of trees) }\end{array}$ & $\begin{array}{l}\text { Luas bidang dasar } \\
\left.\quad(\text { Basal area })^{*}\right)\end{array}$ \\
\hline$\ldots-\ldots$ & $d_{1}$ & $n_{1}$ & $n_{1} \cdot \pi / 40000 . d_{1}^{2}$ \\
\hline$\ldots . . \ldots$ & $d_{2}$ & $n_{2}$ & $n_{2} . \pi / 40000 . d_{2}^{2}$ \\
\hline$\ldots .-\ldots$ & $d_{3}$ & $n_{3}$ & $n_{3} \cdot \pi / 40000 \cdot d_{3}^{2}$ \\
\hline : & $:$ & $:$ & $:$ \\
\hline$:$ & $:$ & $:$ & $:$ \\
\hline$\ldots-\ldots$ & $d_{j}$ & $n_{j}$ & $n_{j} . \pi / 40000 . d_{j}^{2}$ \\
\hline \multicolumn{2}{|c|}{ Jumlah (Total) } & $N$ & $B$ \\
\hline
\end{tabular}

Keterangan (Note) : luas bidang dasar tiap pohon (basal area per tree) $=\pi(1 / 2 d)^{2} \mathrm{~cm}^{2}=1 / 4 \pi d^{2}(1 / 10)^{2} \mathrm{~m}^{2}=\pi / 40000 \mathrm{~d}^{2} \mathrm{~m}^{2}$.

Didasarkan semua uraian di muka, maka dalam penelitian ini parameter-parameter jumlah pohon tiap hektar $(N / h a)$, diameter tegakan $(D s)$, tinggi tegakan $(H s)$ dan luas bidang dasar tegakan tiap hektar $(B / h a)$ digunakan sebagai "parameter kunci". Dengan kata lain, mengingat bahwa tujuan penelitian ini adalah mencari petak ukur (selanjutnya dinotasikan "plot") berukuran terkecil, maka:

- hasil penjabaran jumlah pohon dalam plot ke luas areal 1 ha harus sama dengan jumlah pohon dalam areal standar 1 ha $\left(N / h a_{p l o t}=N / h a_{\text {std }}\right)$,

- diameter tegakan dalam plot harus sama dengan diameter tegakan dalam areal standar 1 ha $\left(D s_{p l o t}=\right.$ $\left.D s_{s t}\right)$,

- tinggi tegakan dalam plot harus sama dengan tinggi tegakan dalam areal standar 1 ha $\left(H s_{p l o t}=H s_{s t d}\right)$,

- hasil penjabaran luas bidang dasar dalam plot ke luas areal 1 ha harus sama dengan bidang dasar dalam areal standar 1 ha $\left(B / h a_{p l o t}=B / h a_{s t d}\right)$. 


\section{B. Bahan Penelitian}

Penelitian dilakukan pada tegakan hutan tanaman Agathis (Agathis loranthifolia Salisb.) di Petak Tanaman 36, Resort Polisi Hutan (RPH) Baturaden, Bagian Kesatuan Pemangkuan Hutan (BKPH) Gunung Slamet Barat, Kesatuan Pemangkuan Hutan (KPH) Banyumas Timur, Perum Perhutani Unit I Jawa Tengah, dengan risalah lokasi sebagai berikut:

1. Letak lokasi penelitian

Berdasarkan administrasi pemerintahan, areal penelitian berada dalam wilayah Desa Karang Salam, Kecamatan Baturaden, Kabupaten Banyumas, Propinsi Jawa Tengah.

Secara geografis Petak Tanaman 36 terletak antara $109^{\circ} 14^{\prime} 01,3^{\prime \prime}-109^{\circ} 14^{\prime} 09,2^{\prime \prime}$ Bujur Timur dan $07^{\circ} 18^{\prime} 08,1^{\prime \prime}-07^{\circ} 18^{\prime} 21,5^{\prime \prime}$ Lintang Selatan. Tinggi tempat (altitude) antara 790-840 meter di atas permukaan laut ( $\mathrm{m} \mathrm{dpl}$ ) dengan topografi beragam dari landai sampai curam (lereng 8-35\%).

\section{Kondisi tegakan}

Tegakan A. loranthifolia Salisb. dalam Petak Tanaman 36 berumur 54 tahun (ditanam tahun 1954). Pada awalnya tegakan Agathis tersebut ditanam dengan jarak tanam $3 \mathrm{~m} \times 2 \mathrm{~m}$, tetapi pada saat penelitian letak pohon sudah tidak tampak dalam bentuk larikan-larikan karena adanya perlakuan penjarangan dan kematian alami (mortality), atau dengan kata lain letak pohon sudah tampak tidak beraturan. Penutupan tegakan terhadap bidang petak tanaman pada umumnya merata, kecuali pada jurang terdapat "areal kosong" berisi belukar atau tumbuhan bambu (Bambusa spp.). Lantai hutan di bawah tegakan ditumbuhi Pacing (Costus speciosus (Koenig) J.E. Smith.) amat rapat dan lebat dengan tinggi mencapai $2 \mathrm{~m}$ sampai $2,5 \mathrm{~m}$.

\section{Kondisi tanah}

Tanah dalam Petak Tanaman 36 berasal dari material vulkanis, solum dalam dengan tekstur debu berpasir, berwarna coklat kehitaman. Permukaan tanah tertutup seresah $\pm 5 \mathrm{~cm}$. Bersifat asam pada permukaan $(\mathrm{pH}=4,5)$, kemudian meningkat sampai agak asam pada kedalaman 1 meter $(\mathrm{pH}=6,5)$, dengan $\mathrm{pH}$ rata-rata 5,5, Kapasitas Tukar Kation (KTK) rendah.

\section{Kondisi iklim}

Curah hujan di BKPH Baturaden rata-rata sebesar $4.650 \mathrm{~mm} /$ tahun, termasuk tipe B; suhu harian berkisar $20^{\circ} \mathrm{C}-23^{\circ} \mathrm{C}$; dan kelembaban udara berkisar $81 \%-89 \%$ (Anonim, 2002).

\section{Metode Pengumpulan Data}

Pengumpulan data dilakukan dengan membuat 5 bidang areal sampel berukuran $120 \mathrm{~m}$ x $120 \mathrm{~m}$. Letak areal sampel dipilih secara sengaja (purposif) dengan memilih lokasi yang sebaran pohonnya merata (semaksimal mungkin menutup seluruh areal $120 \mathrm{~m}$ x $120 \mathrm{~m}$ ), dan lereng lapangan tidak terlalu berat (sedatar mungkin).

Semua pohon di dalam areal sampel dipetakan letaknya, serta diukur keliling batang setinggi dada (1,30 $\mathrm{m}$ di atas tanah) dan tingginya (sampai pucuk). Data letak pohon diukur dengan sistem sumbu salib, dengan pengukuran jarak datar dari sumbu batang pohon terhadap dua garis batas areal yang ditetapkan sebagai sumbu- $x$ dan sumbu- $y$. Pengukuran letak pohon menggunakan meteran jarak, sedangkan keliling batang diukur dengan pita keliling (meet-band), dan pengukuran tinggi pohon menggunakan hagameter. 


\section{Analisis Data}

1. Pohon-pohon dalam areal standar

Berdasarkan peta letak pohon, pada masing-masing areal sampel $120 \mathrm{~m} \mathrm{x} 120 \mathrm{~m}$ dibuat 9 areal standar $100 \mathrm{~m}$ x $100 \mathrm{~m}$ dengan koordinat titik pusat dan koordinat letak pohon yang tercakup di dalamnya dirinci dalam Lampiran-2.

\section{Pohon-pohon dalam plot}

Pada tiap areal standar dianalisis 8 ukuran plot bujur sangkar dengan letak titik pusat berimpit dengan titik pusat areal standar. Kedelapan ukuran plot tersebut adalah $90 \mathrm{~m}$ x $90 \mathrm{~m}, 80 \mathrm{~m}$ x $80 \mathrm{~m}$, $70 \mathrm{~m}$ x $70 \mathrm{~m}, 60 \mathrm{~m}$ x $60 \mathrm{~m}, 50 \mathrm{~m}$ x $50 \mathrm{~m}, 40 \mathrm{~m}$ x $40 \mathrm{~m}, 30 \mathrm{~m}$ x $30 \mathrm{~m}$, dan $20 \mathrm{~m}$ x $20 \mathrm{~m}$. Rincian koordinat letak pohon yang tercakup dalam masing-masing plot dapat dilihat pada Lampiran 3 .

\section{Jumlah pohon tiap hektar}

Jumlah pohon dalam areal standar adalah hasil pencacahan individu pohon yang tercakup di dalam areal standar yang bersangkutan. Dalam penelitian ini jumlah pohon dalam areal standar ditempatkan sebagai jumlah pohon aktual dan dinotasikan dengan $N / h a_{\text {std* }^{*}}$

Jumlah pohon dalam plot adalah hasil pencacahan individu pohon yang letaknya berada di dalam plot yang bersangkutan. Dugaan jumlah pohon tiap hektar merupakan hasil bagi jumlah pohon dalam plot dengan luas plot.

$$
N / h a_{\text {plot }}=\frac{n_{\text {plot }}}{W}
$$

dimana:

$$
\begin{array}{ll}
N / h a_{\text {plot }} & : \text { dugaan jumlah pohon tiap hektar berdasar jumlah pohon dalam plot, } \\
n_{\text {plot }} & : \text { jumlah pohon dalam plot, } \\
W & : \text { luas plot (dalam satuan hektar). }
\end{array}
$$

\section{Diameter tegakan}

Diameter batang masing-masing pohon diperoleh dari hasil penjabaran keliling batang $(D=$ Keliling/ $\pi$ ). Selanjutnya, mengingat Avery dan Burkhart (2002) serta Husch et al. (2003) menyatakan bahwa diameter tegakan adalah nilai rata-rata diameter semua pohon, maka diameter tegakan aktual, yaitu diameter tegakan dalam areal standar, dihitung dengan Persamaan 2; dan dugaan diameter tegakan, yaitu diameter tegakan berdasar diameter pohon-pohon di dalam plot, dihitung dengan Persamaan 3.

$$
\begin{aligned}
& D s_{s t d}=\frac{\stackrel{n_{s t d}}{=} D_{i}}{n_{s t d}} \\
& D s_{\text {plot }}=\frac{\stackrel{n_{\text {plot }}}{=} D_{j}}{n_{\text {plot }}}
\end{aligned}
$$

Dimana:

$D s_{s t d}$ : diameter tegakan aktual, dihitung berdasar diameter pohon-pohon di dalam areal standar,

$D s_{\text {plot }}$ : dugaan diameter tegakan, dihitung berdasar diameter pohon-pohon di dalam plot,

$D_{i}$ : diameter pohon-pohon di dalam areal standar, 
$D_{j} \quad$ : diameter pohon-pohon di dalam plot,

$i=1,2,3, \ldots \ldots \ldots, n_{\text {std }}$

$j=1,2,3, \ldots \ldots \ldots . ., n_{\text {plot }}$

$n_{\text {std }} \quad$ : jumlah pohon dalam areal standar,

$n_{\text {plot }}:$ jumlah pohon dalam plot,

\section{Tinggi tegakan}

Tinggi tegakan adalah nilai rata-rata dari tinggi semua pohon (Avery dan Burkhart, 2002; serta Husch et al., 2003), sehingga tinggi tegakan aktual, yaitu tinggi tegakan dalam areal standar, dihitung dengan Persamaan 4; dan dugaan tinggi tegakan, yaitu tinggi tegakan berdasar tinggi pohon-pohon di dalam plot, dihitung dengan Persamaan 5.

$$
\begin{array}{r}
\qquad s_{\text {std }}=\frac{\stackrel{n_{\text {std }}}{=} H_{i}}{n_{\text {std }}} \\
H s_{\text {plot }}=\frac{\stackrel{\substack{n_{\text {plot }} \\
=}}{j=1} H_{j}}{n_{\text {plot }}}
\end{array}
$$

dimana:

$H s_{s t d}$ : tinggi tegakan aktual, dihitung berdasar tinggi pohon-pohon di dalam areal standar,

$H s_{p l o t}$ : dugaan tinggi tegakan, dihitung berdasar tinggi pohon-pohon di dalam plot,

$H_{i} \quad$ : tinggi pohon-pohon di dalam areal standar,

$H_{j} \quad$ : tinggi pohon-pohon di dalam plot,

$i=1,2,3$,

$j=1,2,3$ ,$n_{s t d}$

$n_{\text {std }} \quad$ : jumlah pohon dalam areal standar,

$n_{\text {plot }}:$ jumlah pohon dalam plot.

6. Luas bidang dasar tegakan tiap hektar

Luas bidang dasar tegakan adalah jumlah luas bidang dasar semua pohon, sehingga luas bidang dasar aktual, yaitu luas bidang dasar dalam areal standar, dihitung dengan Persamaan 6; dan dugaan luas bidang dasar, yaitu luas bidang dasar berdasar luas bidang dasar pohon-pohon di dalam plot, dihitung dengan Persamaan 7.

$$
\begin{aligned}
B / h a_{\text {std }}= & \frac{=}{40000} \underset{i=1}{=} D_{\text {std }} D_{i}^{2} \\
B / h a_{\text {plot }}= & \frac{\frac{=}{40000} \stackrel{n_{\text {plot }}}{=} D_{j=1}^{2}}{W}
\end{aligned}
$$

dimana:

$B / h a_{s t d}$ : luas bidang dasar aktual, dihitung berdasar luas bidang dasar pohon-pohon di dalam areal standar, 
$B / h a_{p l o t}$ : dugaan luas bidang dasar, dihitung berdasar luas bidang dasar pohon-pohon di dalam plot dan luas plot,

$D_{i} \quad$ : diameter pohon-pohon di dalam areal standar,

$D_{j} \quad$ : diameter pohon-pohon di dalam plot,

$i=1,2,3, \ldots \ldots \ldots, n_{\text {std }}$

$j=1,2,3, \ldots \ldots \ldots . . ., n_{\text {plot }}$

$n_{\text {std }} \quad$ : jumlah pohon dalam areal standar,

$n_{p l o t} \quad$ : jumlah pohon dalam plot,

$W \quad$ : luas plot (dalam satuan hektar).

7. Uj i kesamaan tegakan plot vs areal standar

Uji keseragaman parameter tegakan di dalam plot dibandingkan dengan tegakan di dalam areal standar dilakukan dengan menghitung nilai khi-kuadrat (chi-square) menggunakan rumus yang disarankan Steel dan Torrie (1980), Sokal dan Rohlf(1995), serta Kutner et al. (2005).

$$
=^{2}=\underset{k=1}{=} \frac{\left(Y_{s t d}=Y_{p l o t}\right)^{2}}{Y_{p l o t}}
$$

dimana:

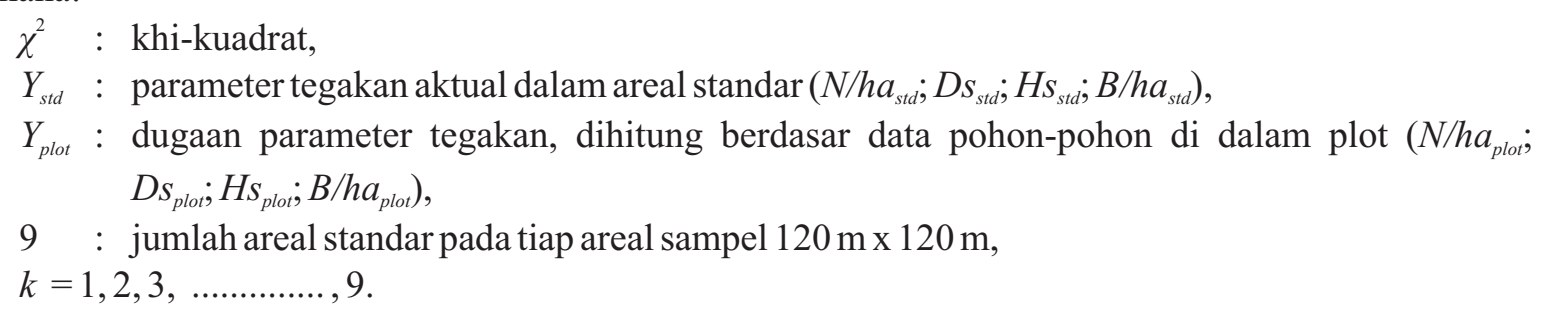

\section{HASIL DAN PEMBAHASAN}

\section{A. Hasil}

1. Parameter jumlah pohon tiap hektar $(N / h a)$

Rekapitulasi hasil perhitungan nilai $\chi^{2}$ dari uji keseragaman $N / h a_{\text {plot }}$ dibandingkan $N / h a_{\text {std }}$ dirangkum dalam Lampiran 4, dan Tabel 2 merupakan interpretasi nilai-nilai $\chi^{2}$ tersebut ke dalam bahasa yang lebih komunikatif agar lebih mudah pembacaannya.

2. Parameter diameter tegakan $(D s)$

Rekapitulasi hasil perhitungan nilai $\chi^{2}$ dari uji keseragaman $D s_{\text {plot }}$ dibandingkan $\mathrm{Ds}_{\text {std }}$ dirangkum dalam Lampiran 5, dan hasil interpretasinya disajikan dalam Tabel 3. 
Tabel(Table)2. Hasil uji keseragaman jumlah pohon tiap hektar dalam plot dibandingkan dengan jumlah pohon dalam areal standar $100 \mathrm{~m} \times 100 \mathrm{~m}$ (Homogenity test result of number of trees per hectare in plot compared to number of trees in standard areas $100 \mathrm{~m} \times 100 \mathrm{~m}$ )

\begin{tabular}{|c|c|c|c|c|c|}
\hline \multirow{2}{*}{$\begin{array}{c}\text { Ukuran plot } \\
(\text { Plot size })\end{array}$} & \multicolumn{5}{|c|}{ Areal contoh (Sample area) $120 \mathrm{~m} \times 120 \mathrm{~m}$} \\
\cline { 2 - 3 } & ke-1 $\left(1^{\text {st }}\right)$ & ke-2 $\left(2^{\text {nd }}\right)$ & ke-3 $\left(3^{\text {rd }}\right)$ & ke-4 $\left(4^{\text {th }}\right)$ & ke-5 $\left(5^{\text {th }}\right)$ \\
\hline $90 \mathrm{~m} \times 90 \mathrm{~m}$ & beda & beda & tak beda & beda & beda \\
\cline { 2 - 3 } & tak beda & tak beda & tak beda & tak beda & beda \\
\cline { 2 - 3 } $70 \mathrm{~m} \times 70 \mathrm{~m}$ & beda & beda & tak beda & beda & beda \\
$60 \mathrm{~m} \times 60 \mathrm{~m}$ & beda & beda & tak beda & beda & beda \\
$50 \mathrm{~m} \times 50 \mathrm{~m}$ & beda & beda & beda & beda & beda \\
$40 \mathrm{~m} \times 40 \mathrm{~m}$ & beda & beda & beda & beda & beda \\
$30 \mathrm{~m} \times 30 \mathrm{~m}$ & beda & beda & beda & beda & beda \\
$20 \mathrm{~m} \times 20 \mathrm{~m}$ & beda & beda & beda & beda & beda \\
\hline
\end{tabular}

Keterangan(Notes): beda: berbeda nyata pada taraf kepercayaan 95\% (significantly different at 95\% confidence level); tak beda: tidak berbeda nyata pada taraf kepercayaan 95\% (not significantly different at $95 \%$ confidence level)

Tabel(Table)3. Hasil uji keseragaman diameter tegakan dalam plot dibandingkan dengan diameter tegakan dalam areal standar $100 \mathrm{~m}$ x $100 \mathrm{~m}$ (Homogenity test result of stand diameter in plot compared to stand diameter in standard areas $100 \mathrm{~m} \times 100 \mathrm{~m}$ )

\begin{tabular}{|c|c|c|c|c|c|}
\hline \multirow{2}{*}{$\begin{array}{c}\text { Ukuran plot } \\
(\text { Plot size })\end{array}$} & \multicolumn{5}{|c|}{ Areal contoh (Sample area) $120 \mathrm{~m} \times 120 \mathrm{~m}$} \\
\cline { 2 - 6 } & ke-1 $\left(1^{\text {st }}\right)$ & ke-2 $\left(2^{\text {nd }}\right)$ & ke-3 $\left(3^{\text {rd }}\right)$ & ke-4 $\left(4^{\text {th }}\right)$ & ke-5 $\left(5^{\text {th }}\right)$ \\
\hline $90 \mathrm{~m} \times 90 \mathrm{~m}$ & tak beda & tak beda & tak beda & tak beda & tak beda \\
$80 \mathrm{~m} \times 80 \mathrm{~m}$ & tak beda & tak beda & tak beda & tak beda & tak beda \\
$70 \mathrm{~m} \times 70 \mathrm{~m}$ & tak beda & tak beda & tak beda & tak beda & tak beda \\
$60 \mathrm{~m} \times 60 \mathrm{~m}$ & tak beda & tak beda & tak beda & tak beda & tak beda \\
$50 \mathrm{~m} \times 50 \mathrm{~m}$ & tak beda & tak beda & tak beda & tak beda & tak beda \\
$40 \mathrm{~m} \times 40 \mathrm{~m}$ & tak beda & tak beda & tak beda & tak beda & tak beda \\
$30 \mathrm{~m} \times 30 \mathrm{~m}$ & tak beda & tak beda & tak beda & tak beda & tak beda \\
$20 \mathrm{~m} \times 20 \mathrm{~m}$ & tak beda & tak beda & beda & tak beda & tak beda \\
\hline
\end{tabular}

Keterangan (Notes): beda: berbeda nyata pada taraf kepercayaan 95\% (significantly different at 95\% confidence level); tak beda: tidak berbeda nyata pada taraf kepercayaan 95\% (not significantly different at $95 \%$ confidencelevel)

\section{Parameter tinggi tegakan $(H s)$}

Rekapitulasi hasil perhitungan nilai $\chi^{2}$ dari uji keseragaman $H s_{\text {plot }}$ dibandingkan $H s_{s t d}$ dirangkum dalam Lampiran 6, dan hasil interpretasinya disajikan dalam Tabel 4. 
Tabel(Table) 4: Hasil uji keseragaman tinggi tegakan dalam plot dibandingkan dengan tinggi tegakan dalam areal standar $100 \mathrm{~m} \times 100 \mathrm{~m}$ (Homogenity test result of stand height in plot compared with stand height in standard areas $100 \mathrm{~m} \times 100 \mathrm{~m}$ )

\begin{tabular}{|c|c|c|c|c|c|}
\hline \multirow{2}{*}{$\begin{array}{c}\text { Ukuran plot } \\
(\text { Plot size })\end{array}$} & \multicolumn{5}{|c|}{ Areal contoh (Sample area) $120 \mathrm{~m} \times 120 \mathrm{~m}$} \\
\cline { 2 - 6 } & ke-1 $\left(1^{\text {st }}\right)$ & ke-2 $\left(2^{\text {nd }}\right)$ & ke-3 $\left(3^{\text {rd }}\right)$ & ke-4 $\left(4^{\text {th }}\right)$ & ke-5 $\left(5^{\text {th }}\right)$ \\
\hline $90 \mathrm{~m} \times 90 \mathrm{~m}$ & tak beda & tak beda & tak beda & tak beda & tak beda \\
$80 \mathrm{~m} \times 80 \mathrm{~m}$ & tak beda & tak beda & tak beda & tak beda & tak beda \\
$70 \mathrm{~m} \times 70 \mathrm{~m}$ & tak beda & tak beda & tak beda & tak beda & tak beda \\
$60 \mathrm{~m} \times 60 \mathrm{~m}$ & tak beda & tak beda & tak beda & tak beda & tak beda \\
$50 \mathrm{~m} \times 50 \mathrm{~m}$ & tak beda & tak beda & tak beda & tak beda & tak beda \\
$40 \mathrm{~m} \times 40 \mathrm{~m}$ & tak beda & tak beda & tak beda & tak beda & tak beda \\
$30 \mathrm{~m} \times 30 \mathrm{~m}$ & tak beda & tak beda & tak beda & tak beda & tak beda \\
$20 \mathrm{~m} \times 20 \mathrm{~m}$ & tak beda & tak beda & tak beda & tak beda & tak beda \\
\hline
\end{tabular}

Keterangan (Note): tak beda: tidak berbeda nyata pada taraf kepercayaan 95\% (not significantly different at 95\% confidence level)

4. Parameter luas bidang dasar tegakan tiap hektar $(B / h a)$

Rekapitulasi hasil perhitungan nilai $\chi^{2}$ dari uji keseragaman $B / h a_{p l o t}$ dibandingkan $B / h a_{\text {std }}$ dirangkum dalam Lampiran 7, dan hasil interpretasinya disajikan dalam Tabel 5.

Tabel(Table) 5: Hasil uji keseragaman luas bidang dasar tegakan tiap hektar dalam plot dibandingkan dengan luas bidang dasar tegakan dalam areal standar $100 \mathrm{~m}$ x $100 \mathrm{~m}$ (Homogenity test result of basal area per hectare in plot compared with basal area in standard areas

\begin{tabular}{|c|c|c|c|c|c|}
\hline \multirow{2}{*}{$\begin{array}{l}\text { Ukuran plot } \\
\text { (Plot size ) }\end{array}$} & \multicolumn{5}{|c|}{ Areal contoh (Sample area) $120 \mathrm{~m} \times 120 \mathrm{~m}$} \\
\hline & ke-1 $\left(1^{s t}\right)$ & ke-2 $\left(2^{\text {nd }}\right)$ & ke-3 $\left(3^{\text {rd }}\right)$ & ke-4 $\left(4^{\text {th }}\right)$ & ke-5 $\left(5^{\text {th }}\right)$ \\
\hline $90 \mathrm{~m} \times 90 \mathrm{~m}$ & tak beda & tak beda & tak beda & tak beda & tak beda \\
\hline $80 \mathrm{~m} \times 80 \mathrm{~m}$ & tak beda & tak beda & tak beda & tak beda & tak beda \\
\hline $70 \mathrm{~m} \times 70 \mathrm{~m}$ & tak beda & tak beda & tak beda & tak beda & tak beda \\
\hline $60 \mathrm{~m} \times 60 \mathrm{~m}$ & tak beda & tak beda & tak beda & tak beda & tak beda \\
\hline $50 \mathrm{~m} \times 50 \mathrm{~m}$ & tak beda & tak beda & tak beda & tak beda & tak beda \\
\hline $40 \mathrm{~m} \times 40 \mathrm{~m}$ & tak beda & tak beda & tak beda & tak beda & tak beda \\
\hline $30 \mathrm{~m} \times 30 \mathrm{~m}$ & tak beda & beda & beda & beda & beda \\
\hline $20 \mathrm{~m} \times 20 \mathrm{~m}$ & beda & beda & beda & beda & beda \\
\hline
\end{tabular}

\section{B. Pembahasan}

Dengan asumsi plot sebagai wakil atau sampel dari areal hutan seluas 1 hektar, berdasar hasil uji keseragaman kondisi tegakan dalam Tabel 2 sampai dengan Tabel 5 diperoleh informasi bahwa masingmasing parameter tegakan mempunyai tingkat kepekaan yang berbeda terhadap ukuran plot. Tinggi tegakan merupakan parameter yang paling tidak peka terhadap perubahan ukuran plot. Dalam Tabel 4 terlihat bahwa pada semua ukuran plot (bahkan sampai ukuran $20 \mathrm{~m}$ x $20 \mathrm{~m}$ ), nilai rata-rata tinggi pohon di dalam plot tidak berbeda nyata dengan nilai rata-rata tinggi pohon di dalam areal seluas 1 ha. Dengan kata lain, untuk mengetahui tinggi tegakan hutan tanaman Agathis berumur lebih dari 50 tahun 
seluas 1 ha tidak perlu melakukan pengukuran seluruh pohon pada areal tersebut, melainkan dapat diwakili dengan pengukuran tinggi pohon pada areal seluas $400 \mathrm{~m}^{2}(20 \mathrm{~m} \times 20 \mathrm{~m})$.

Diameter tegakan merupakan parameter tegakan yang menempati urutan kedua tingkat ketidakpekaannya terhadap ukuran plot. Dalam Tabel 3 terlihat bahwa apabila dilakukan pengukuran diameter pohon Agathis dengan plot berukuran $20 \mathrm{~m}$ x $20 \mathrm{~m}$ maka ada peluang sebesar $\pm 20 \%$ nilai diameter tegakan yang diperoleh tidak sama dengan diameter tegakan dari areal seluas 1 ha. Kemudian apabila ukuran plot diperbesar menjadi $30 \mathrm{~m}$ x $30 \mathrm{~m}$ maka sangat besar kemungkinannya nilai diameter tegakan yang diperoleh sama dengan diameter tegakan dari areal seluas $1 \mathrm{ha}$.

Luas bidang dasar merupakan parameter tegakan yang menempati urutan ketiga tingkat ketidakpekaannya terhadap ukuran plot; yaitu plot terkecil yang dapat mewakili luas bidang dasar tegakan seluas 1 ha adalah plot ukuran $40 \mathrm{~m}$ x $40 \mathrm{~m}$ (lihat Tabel 5). Kemudian parameter tegakan yang sangat peka terhadap perubahan ukuran plot adalah jumlah pohon tiap hektar. Dalam Tabel 2 terlihat bahwa sangat besar kemungkinannya hasil pencacahan pohon dalam areal kurang dari 1 ha tidak sama dengan jumlah pohon aktual dalam areal seluas 1 ha. Dengan kata lain, mengingat bahwa petak ukur permanen (PUP) adalah "miniatur" tegakan (yang diwakilinya), sebaiknya data jumlah pohon tiap hektar tidak diwakili dengan pengukuran areal kurang dari 1 ha.

Dalam kegiatan pengukuran PUP, pengukuran diameter dan tinggi pohon-pohon di dalam PUP merupakan pekerjaan yang menuntut tenaga dan waktu cukup besar; bahkan pengukuran tinggi pohon merupakan pekerjaan yang paling menuntut tenaga dan waktu. Colbert et al. (2002) menyebutkan bahwa bagaimanapun pengukuran tinggi pohon merupakan pekerjaan yang relatif sulit dan membutuhkan biaya relatif besar karena: ${ }^{(1)}$ membutuhkan waktu relatif lama, ${ }^{(2)}$ mudah terjadi kesalahan pengukuran, dan ${ }^{(3)}$ hambatan visual akibat rapatnya penutupan tajuk.

Didasarkan kenyataan bahwa disatu pihak jumlah pohon tiap hektar merupakan parameter tegakan yang sangat peka terhadap pengecilan ukuran PUP, sedangkan parameter tersebut (bersama parameter luas bidang dasar) berperan sangat penting dalam penggambaran struktur tegakan, dan di lain pihak pengukuran diameter dan tinggi pohon merupakan pekerjaan yang menuntut tenaga, waktu, dan biaya, maka solusi ukuran optimal PUP hutan tanaman Agathis adalah areal $100 \mathrm{~m}$ x $100 \mathrm{~m}$ yang di tengahnya dibuat petak $40 \mathrm{~m} \times 40 \mathrm{~m}$ seperti terlihat dalam Gambar 1 .

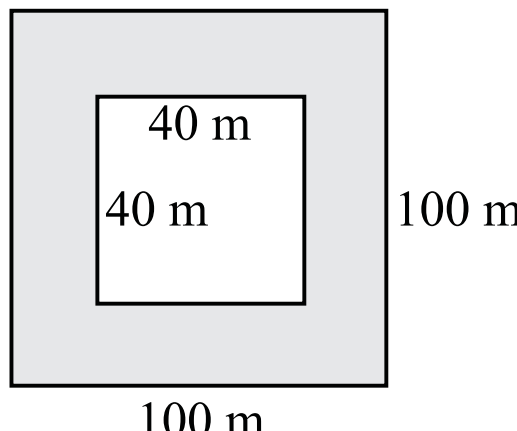

Gambar(Figure) 1. Bentuk dan ukuran optimal petak ukur permanen (PUP) hutan tanaman Agathis (Shape and size of permanent sample plot (PSP) that is optimal for Agathis loranthifolia Salisb. plantation forest) 
Pada saat pembuatan dan pengukuran PUP, semua pohon dalam petak $100 \mathrm{~m}$ x $100 \mathrm{~m}$ (termasuk pohon-pohon di dalam petak $40 \mathrm{~m}$ x $40 \mathrm{~m}$ ) diberi nomor secara berurutan. Penomoran pohon ini sekaligus merupakan kegiatan pencacahan pohon. Kegiatan pengukuran keliling batang dan tinggi pohon dilakukan terbatas pada pohon-pohon di dalam petak $40 \mathrm{~m}$ x $40 \mathrm{~m}$. Dengan cara ini diperoleh efisiensi pencurahan tenaga dengan seluruh sasaran pengumpulan data dapat tercapai.

\section{KESIMPULAN DAN SARAN}

\section{A. Kesimpulan}

1. Informasi pertumbuhan tegakan secara lengkap dan faktual hanya diperoleh melalui pembuatan dan pengukuran petak ukur permanen (PUP) dengan ukuran yang optimal.

2. Untuk memperoleh data pertumbuhan tegakan secara lengkap dan untuk efisiensi pencurahan tenaga, bentuk dan ukuran PUP yang optimal untuk hutan tanaman Agathis (Agathis loranthifolia Salisb.) adalah petak bujur sangkar $100 \mathrm{~m}$ x $100 \mathrm{~m}$ yang di tengahnya dibuat petak berukuran $40 \mathrm{~m}$ x $40 \mathrm{~m}$. Petak $100 \mathrm{~m} \times 100 \mathrm{~m}$ digunakan untuk pemantauan dinamika jumlah pohon, sedangkan petak $40 \mathrm{~m} \times 40 \mathrm{~m}$ digunakan untuk pemantauan riap diameter dan tinggi tegakan.

\section{B. Saran}

Sebaiknya penelitian semacam ini dilakukan pada jenis tanaman hutan lainnya agar diperoleh bahan yang menyeluruh untuk penyusunan petunjuk teknis (Juknis) tatacara pembuatan dan pengukuran PUPhutan tanaman.

\section{DAFTAR PUSTAKA}

Alder, D. 1980. Forest Volume Estimation and Yield Prediction. FAO, Rome.

Anonim. 2002. Rencana Pengaturan Kelestarian Hutan (RPKH) Kelas Perusahaan Damar Kesatuan Pemangkuan Hutan Banyumas Timur, Jangka Perusahaan I Januari 2003 s/d 31 Desember 2012. Lampiran I, Lembar: 1. Seksi Perencanaan Hutan II Yogyakarta, Perum Perhutani Unit I JawaTengah, Yogyakarta.

Avery, T. E. and H. E. Burkhart. 2002. Forest Measurements. McGraw-Hill, New York.

Colbert, K. C., D. R. Larsen and J. R. Lootens. 2002. Height-Diameter Equations for Thirteen Midwestern Bottomland Hardwood Species. Northern Journal ofA pplied Forestry 19: 171-176.

Departemen Kehutanan. 1995. Keputusan Menteri Kehutanan Nomor 237/Kpts-11/95 tentang Pembuatan dan Pengukuran Petak Ukur Permanen untuk Pemantauan Riap Tegakan.

Husch, B., T. W. Beers and J. A. Kershaw. 2003. Forest Mensuration. Fourth Edition. John Wiley and Sons, Inc, New York.

Kutner, M. H., C. J. Nachtsheim, J. Neter and W. Li. 2005. Applied Linear Statistical Models. McGrawHill lrwin, Boston.

Priyadi, H., P. Gunarso and M. Kanninen. 2006. Workshop Summary. In Priyadi, H., P. Gunarso and M. Kanninen, (Eds). Permanent Sample Plots: More than Just Forest Data. Center for International Forestry Reseach. pp: xvi-xviii. 
Sokal, R. R. and F. J. Rohlf. 1995. Biometry: the Principles and Practice of Statistics in Biological Research. W. H. Freeman, New York.

Steel, R. G. D. and J. H. Torrie. 1980. Principles and Procedures of Statistics. Second Edition. McGrawHill Book Company, lnc, NewYork.

Vanclay, J. K. 1994. Modelling Forest Growth and Yield (Application to Mixed Tropical Forest). CAB International, Wallingford, UK. 


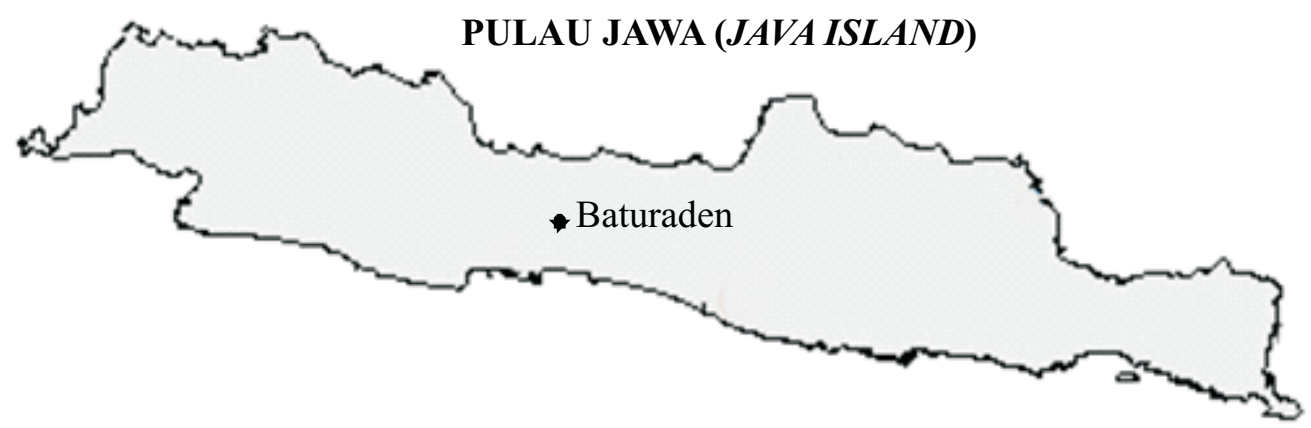

Lampiran (Appendix) 2. Koordinat titik pusat areal standar $100 \mathrm{~m} \times 100 \mathrm{~m}$ di dalam tiap areal contoh $120 \mathrm{~m} \times 120 \mathrm{~m}$ (Coordinates of $100 \mathrm{~m} \times 100 \mathrm{~m}$ standard area centre point in each $120 m \times 120$ m sample area)

\begin{tabular}{|c|c|c|}
\hline $\begin{array}{c}\text { Nomor } \\
\text { areal standar } \\
\begin{array}{c}\text { Standard area } \\
\text { number) }\end{array}\end{array}$ & $\begin{array}{c}\text { Koordinat titik pusat } \\
\text { areal standar } \\
\text { The coordinates of } \\
\text { standard area } \\
\text { centre-point) }\end{array}$ & $\begin{array}{c}\text { Koordinat letak pohon-pohon } \\
\text { yang tercakup } \\
\text { (Trees location coordinate } \\
\text { to be covered) }\end{array}$ \\
\hline$(1)$ & $(2)$ & (3) \\
\hline 1 & $(50 ; 60)$ & $0=x=100$ dan (and) $0=y=100$ \\
2 & $(50 ; 70)$ & $0=x=100$ dan (and) $10=y=110$ \\
3 & $(60 ; 50)$ & $10=x=110$ dan (and) $0=y=100$ \\
4 & $(60 ; 60)$ & $10=x=110$ dan (and) $10=y=110$ \\
5 & $(60 ; 70)$ & $10=x=110$ dan (and) $20=y=120$ \\
6 & $(70 ; 50)$ & $20=x=120$ dan (and) $0=y=100$ \\
7 & $(70 ; 60)$ & $20=x=120$ dan (and) $10=y=110$ \\
9 & $(70 ; 70)$ & $20=x=120$ dan (and) $20=y=120$ \\
\hline
\end{tabular}


Lampiran(Appendix) 3: Koordinat titik pusat plot dan koordinat letak pohon yang tercakup (Coordinates of plot centre-point and tree location coordinates to be covered)

\begin{tabular}{|c|c|c|}
\hline $\begin{array}{c}\text { Koordinat } \\
\text { titik pusat plot } \\
\text { (The coordinates of plot } \\
\text { centre-point) }\end{array}$ & $\begin{array}{l}\text { Ukuran plot } \\
\text { (Plot size) }\end{array}$ & $\begin{array}{l}\text { Koordinat letak pohon-pohon } \\
\text { yang tercakup } \\
\text { (Trees location coordinate } \\
\text { to be covered) }\end{array}$ \\
\hline (1) & (2) & (3) \\
\hline$(50 ; 50)$ & $\begin{array}{l}80 \mathrm{~m} \times 80 \mathrm{~m} \\
70 \mathrm{~m} \times 70 \mathrm{~m} \\
60 \mathrm{~m} \times 60 \mathrm{~m} \\
50 \mathrm{~m} \times 50 \mathrm{~m} \\
40 \mathrm{~m} \times 40 \mathrm{~m} \\
30 \mathrm{~m} \times 30 \mathrm{~m} \\
20 \mathrm{~m} \times 20 \mathrm{~m}\end{array}$ & $\begin{array}{rll}5=x=95 & \text { dan (and) } & 5=y=95 \\
10=x=90 & \text { dan (and) } & 10=y=90 \\
15=x=85 & \text { dan (and) } & 15=y=85 \\
20=x=80 & \text { dan (and) } & 20=y=80 \\
25=x=75 & \text { dan (and) } & 25=y=75 \\
30=x=70 & \text { dan (and) } & 30=y=70 \\
35=x=65 & \text { dan (and) } & 35=y=65 \\
40=x=60 & \text { dan (and) } & 40=y=60\end{array}$ \\
\hline$(50 ; 60)$ & $\begin{array}{l}90 \mathrm{~m} \times 90 \mathrm{~m} \\
80 \mathrm{~m} \times 80 \mathrm{~m} \\
70 \mathrm{~m} \times 70 \mathrm{~m} \\
60 \mathrm{~m} \times 60 \mathrm{~m} \\
50 \mathrm{~m} \times 50 \mathrm{~m} \\
40 \mathrm{~m} \times 40 \mathrm{~m} \\
30 \mathrm{~m} \times 30 \mathrm{~m} \\
20 \mathrm{~m} \times 20 \mathrm{~m}\end{array}$ & $\begin{array}{ccc}5=x=95 & \text { dan (and) } & 15=y=105 \\
10=x=90 & \text { dan (and) } & 20=y=100 \\
15=x=85 & \text { dan (and) } & 25=y=95 \\
20=x=80 & \text { dan (and) } & 30=y=90 \\
25=x=75 & \text { dan (and) } & 35=y=85 \\
30=x=70 & \text { dan (and) } & 40=y=80 \\
35=x=65 & \text { dan (and) } & 45=y=75 \\
40=x=60 & \text { dan (and) } & 50=y=70\end{array}$ \\
\hline$(50 ; 70)$ & $\begin{array}{l}90 \mathrm{~m} \times 90 \mathrm{~m} \\
80 \mathrm{~m} \times 80 \mathrm{~m} \\
70 \mathrm{~m} \times 70 \mathrm{~m} \\
60 \mathrm{~m} \times 60 \mathrm{~m} \\
50 \mathrm{~m} \times 50 \mathrm{~m} \\
40 \mathrm{~m} \times 40 \mathrm{~m} \\
30 \mathrm{~m} \times 30 \mathrm{~m} \\
20 \mathrm{~m} \times 20 \mathrm{~m}\end{array}$ & $\begin{array}{ccc}5=x=95 & \text { dan (and) } & 25=y=115 \\
10=x=90 & \text { dan (and) }) & 30=y=110 \\
15=x=85 & \text { dan (and) } & 35=y=105 \\
20=x=80 & \text { dan (and) } & 40=y=100 \\
25=x=75 & \text { dan (and) } & 45=y=95 \\
30=x=70 & \text { dan (and) } & 50=y=90 \\
35=x=65 & \text { dan (and) } & 55=y=85 \\
40=x=60 & \text { dan (and) } & 60=y=80\end{array}$ \\
\hline$(60 ; 50)$ & $\begin{array}{l}90 \mathrm{~m} \times 90 \mathrm{~m} \\
80 \mathrm{~m} \times 80 \mathrm{~m} \\
70 \mathrm{~m} \times 70 \mathrm{~m} \\
60 \mathrm{~m} \times 60 \mathrm{~m} \\
50 \mathrm{~m} \times 50 \mathrm{~m} \\
40 \mathrm{~m} \times 40 \mathrm{~m} \\
30 \mathrm{~m} \times 30 \mathrm{~m} \\
20 \mathrm{~m} \times 20 \mathrm{~m}\end{array}$ & $\begin{array}{ccc}15=x=105 & \text { dan (and) } & 5=y=95 \\
20=x=100 & \text { dan (and) } & 10=y=90 \\
25=x=95 & \text { dan (and) } & 15=y=85 \\
30=x=90 & \text { dan (and) } & 20=y=80 \\
35=x=85 & \text { dan (and) } & 25=y=75 \\
40=x=80 & \text { dan (and) } & 30=y=70 \\
45=x=75 & \text { dan (and) } & 35=y=65 \\
50=x=70 & \text { dan (and) } & 40=y=60\end{array}$ \\
\hline
\end{tabular}




\begin{tabular}{|c|c|c|}
\hline (1) & (2) & (3) \\
\hline$(60 ; 60)$ & $\begin{array}{l}90 \mathrm{~m} \times 90 \mathrm{~m} \\
80 \mathrm{~m} \times 80 \mathrm{~m} \\
70 \mathrm{~m} \times 70 \mathrm{~m} \\
60 \mathrm{~m} \times 60 \mathrm{~m} \\
50 \mathrm{~m} \times 50 \mathrm{~m} \\
40 \mathrm{~m} \times 40 \mathrm{~m} \\
30 \mathrm{~m} \times 30 \mathrm{~m} \\
20 \mathrm{~m} \times 20 \mathrm{~m}\end{array}$ & $\begin{array}{rll}15=x=105 & \text { dan (and) } & 15=y=105 \\
20=x=100 & \text { dan (and) } & 20=y=100 \\
25=x=95 & \text { dan (and) } & 25=y=95 \\
30=x=90 & \text { dan (and) } & 30=y=90 \\
35=x=85 & \text { dan (and) } & 35=y=85 \\
40=x=80 & \text { dan (and) } & 40=y=80 \\
45=x=75 & \text { dan (and) } & 45=y=75 \\
50=x=70 & \text { dan (and) } & 50=y=70\end{array}$ \\
\hline$(60 ; 70)$ & $\begin{array}{l}90 \mathrm{~m} \times 90 \mathrm{~m} \\
80 \mathrm{~m} \times 80 \mathrm{~m} \\
70 \mathrm{~m} \times 70 \mathrm{~m} \\
60 \mathrm{~m} \times 60 \mathrm{~m} \\
50 \mathrm{~m} \times 50 \mathrm{~m} \\
40 \mathrm{~m} \times 40 \mathrm{~m} \\
30 \mathrm{~m} \times 30 \mathrm{~m} \\
20 \mathrm{~m} \times 20 \mathrm{~m}\end{array}$ & $\begin{array}{ccc}15=x=105 & \text { dan (and) } & 25=y=115 \\
20=x=100 & \text { dan (and) } & 30=y=110 \\
25=x=95 & \text { dan (and) } & 35=y=105 \\
30=x=90 & \text { dan (and) } & 40=y=100 \\
35=x=85 & \text { dan (and) } & 45=y=95 \\
40=x=80 & \text { dan (and }) & 50=y=90 \\
45=x=75 & \text { dan (and) } & 55=y=85 \\
50=x=70 & \text { dan (and) } & 60=y=80\end{array}$ \\
\hline$(70 ; 50)$ & $\begin{array}{l}90 \mathrm{~m} \times 90 \mathrm{~m} \\
80 \mathrm{~m} \times 80 \mathrm{~m} \\
70 \mathrm{~m} \times 70 \mathrm{~m} \\
60 \mathrm{~m} \times 60 \mathrm{~m} \\
50 \mathrm{~m} \times 50 \mathrm{~m} \\
40 \mathrm{~m} \times 40 \mathrm{~m} \\
30 \mathrm{~m} \times 30 \mathrm{~m} \\
20 \mathrm{~m} \times 20 \mathrm{~m}\end{array}$ & $\begin{array}{ccc}25=x=115 & \text { dan (and) } & 5=y=95 \\
30=x=110 & \text { dan (and) } & 10=y=90 \\
35=x=105 & \text { dan (and) } & 15=y=85 \\
40=x=100 & \text { dan (and) } & 20=y=80 \\
45=x=95 & \text { dan (and) } & 25=y=75 \\
50=x=90 & \text { dan (and) } & 30=y=70 \\
55=x=85 & \text { dan (and) } & 35=y=65 \\
60=x=80 & \text { dan (and) } & 40=y=60\end{array}$ \\
\hline$(70 ; 60)$ & $\begin{array}{l}90 \mathrm{~m} \times 90 \mathrm{~m} \\
80 \mathrm{~m} \times 80 \mathrm{~m} \\
70 \mathrm{~m} \times 70 \mathrm{~m} \\
60 \mathrm{~m} \times 60 \mathrm{~m} \\
50 \mathrm{~m} \times 50 \mathrm{~m} \\
40 \mathrm{~m} \times 40 \mathrm{~m} \\
30 \mathrm{~m} \times 30 \mathrm{~m} \\
20 \mathrm{~m} \times 20 \mathrm{~m}\end{array}$ & $\begin{array}{ccc}25=x=115 & \text { dan (and) } & 15=y=105 \\
30=x=110 & \text { dan (and) } & 20=y=100 \\
35=x=105 & \text { dan (and }) & 25=y=95 \\
40=x=100 & \text { dan (and }) & 30=y=90 \\
45=x=95 & \text { dan (and) } & 35=y=85 \\
50=x=90 & \text { dan (and }) & 40=y=80 \\
55=x=85 & \text { dan (and) } & 45=y=75 \\
60=x=80 & \text { dan (and }) & 50=y=70\end{array}$ \\
\hline$(70 ; 70)$ & $\begin{array}{l}90 \mathrm{~m} \times 90 \mathrm{~m} \\
80 \mathrm{~m} \times 80 \mathrm{~m} \\
70 \mathrm{~m} \times 70 \mathrm{~m} \\
60 \mathrm{~m} \times 60 \mathrm{~m} \\
50 \mathrm{~m} \times 50 \mathrm{~m} \\
40 \mathrm{~m} \times 40 \mathrm{~m} \\
30 \mathrm{~m} \times 30 \mathrm{~m} \\
20 \mathrm{~m} \times 20 \mathrm{~m}\end{array}$ & $\begin{array}{rll}25=x=115 & \text { dan (and) } & 25=y=115 \\
30=x=110 & \text { dan (and) } & 30=y=110 \\
35=x=105 & \text { dan (and) } & 35=y=105 \\
40=x=100 & \text { dan (and) } & 40=y=100 \\
45=x=95 & \text { dan (and) } & 45=y=95 \\
50=x=90 & \text { dan (and) } & 50=y=90 \\
55=x=85 & \text { dan (and) } & 55=y=85 \\
60=x=80 & \text { dan (and) } & 60=y=80\end{array}$ \\
\hline
\end{tabular}


Lampiran (Appendix) 4. Nilai $\chi^{2}$ hasil uji keseragaman jumlah pohon tiap hektar dalam plot dibandingkan dengan jumlah pohon dalam areal standar $100 \mathrm{~m} \times 100 \mathrm{~m}$ (The $\chi^{2}$-values of homogenity test of number of trees per hectare in plot compared with number of trees in standard areas $100 \mathrm{~m} \times 100 \mathrm{~m}$ )

\begin{tabular}{|c|c|c|c|c|c|}
\hline \multirow{2}{*}{$\begin{array}{c}\text { Ukuran plot } \\
(\text { Plot size })\end{array}$} & \multicolumn{5}{|c|}{ Areal contoh (Sample area) $120 \mathrm{~m} \times 120 \mathrm{~m}$} \\
\cline { 2 - 3 } & $\mathrm{ke}-1\left(1^{\text {st }}\right)$ & $\mathrm{ke}-2\left(2^{\text {nd }}\right)$ & $\mathrm{ke}-3\left(3^{\text {rd }}\right)$ & $\mathrm{ke}-4\left(4^{\text {th }}\right)$ & $\mathrm{ke}-5\left(5^{\text {th }}\right)$ \\
\hline $90 \mathrm{~m} \times 90 \mathrm{~m}$ & 6,89 & 6,75 & 1,20 & 3,59 & 9,76 \\
\cline { 2 - 3 } $80 \mathrm{~m} \times 80 \mathrm{~m}$ & 2,61 & 2,35 & 2,08 & 1,30 & 7,10 \\
\cline { 2 - 3 } $70 \mathrm{~m} \times 70 \mathrm{~m}$ & 3,58 & 3,05 & 2,68 & 4,26 & 8,03 \\
$60 \mathrm{~m} \times 60 \mathrm{~m}$ & 3,39 & 5,40 & 1,66 & 2,87 & 14,60 \\
$50 \mathrm{~m} \times 50 \mathrm{~m}$ & 9,23 & 14,76 & 15,48 & 4,27 & 20,57 \\
$40 \mathrm{~m} \times 40 \mathrm{~m}$ & 15,11 & 73,11 & 33,32 & 7,53 & 17,24 \\
$30 \mathrm{~m} \times 30 \mathrm{~m}$ & 21,03 & 144,20 & 81,32 & 28,52 & 35,61 \\
$20 \mathrm{~m} \times 20 \mathrm{~m}$ & 2995,97 & 3557,82 & 644,57 & 1333,73 & 1439,24 \\
\hline
\end{tabular}

Keterangan $($ Note $): \chi_{(0,95 ; 8)}^{2}=2,73$

Lampiran (Appendix) 5. Nilai $\chi^{2}$ hasil uji keseragaman diameter tegakan dalam plot dibandingkan dengan diameter tegakan dalam areal standar $100 \mathrm{~m} \times 100 \mathrm{~m}$ (The $\chi^{2}$-values of homogenity test of stand diameter in plot compared with stand diameter in standard areas $100 \mathrm{~m} \times 100 \mathrm{~m}$ )

\begin{tabular}{|c|c|c|c|c|c|}
\hline \multirow{2}{*}{$\begin{array}{c}\text { Ukuran plot } \\
(\text { Plot size })\end{array}$} & \multicolumn{5}{|c|}{ Areal contoh (Sample area) $120 \mathrm{~m} \times 120 \mathrm{~m}$} \\
\cline { 2 - 6 } & $\mathrm{ke}-1\left(1^{\text {st }}\right)$ & $\mathrm{ke}-2\left(2^{\text {nd }}\right)$ & $\mathrm{ke}-3\left(3^{\text {rd }}\right)$ & $\mathrm{ke}-4\left(4^{\text {th }}\right)$ & $\mathrm{ke}-5\left(5^{\text {th }}\right)$ \\
\hline $90 \mathrm{~m} \times 90 \mathrm{~m}$ & 0,00 & 0,05 & 0,01 & 0,01 & 0,06 \\
$80 \mathrm{~m} \times 80 \mathrm{~m}$ & 0,01 & 0,10 & 0,01 & 0,01 & 0,25 \\
$70 \mathrm{~m} \times 70 \mathrm{~m}$ & 0,06 & 0,05 & 0,07 & 0,09 & 0,32 \\
$60 \mathrm{~m} \times 60 \mathrm{~m}$ & 0,03 & 0,04 & 0,47 & 0,18 & 0,23 \\
$50 \mathrm{~m} \times 50 \mathrm{~m}$ & 0,05 & 0,06 & 1,19 & 0,11 & 0,54 \\
$40 \mathrm{~m} \times 40 \mathrm{~m}$ & 0,10 & 0,17 & 2,17 & 0,28 & 0,92 \\
$30 \mathrm{~m} \times 30 \mathrm{~m}$ & 1,35 & 0,20 & 2,66 & 0,48 & 1,54 \\
$20 \mathrm{~m} \times 20 \mathrm{~m}$ & 2,35 & 2,04 & 4,44 & 0,57 & 2,40 \\
\hline
\end{tabular}

Keterangan (Note): $\chi_{(0,95 ; 8)}^{2}=2,73$ 
Lampiran (Appendix) 6. Nilai $\chi^{2}$ hasil uji keseragaman tinggi tegakan dalam plot dibandingkan dengan tinggi tegakan dalam areal standar $100 \mathrm{~m} \times 100 \mathrm{~m}$ (The $\chi^{2}$-values of homogenity test of stand height in plot compared with stand height in standard areas $100 \mathrm{~m} \times 100 \mathrm{~m}$ )

\begin{tabular}{|c|c|c|c|c|c|}
\hline \multirow{2}{*}{$\begin{array}{c}\text { Ukuran plot } \\
(\text { Plot size })\end{array}$} & \multicolumn{5}{|c|}{ Areal contoh (Sample area) $120 \mathrm{~m} \times 120 \mathrm{~m}$} \\
\cline { 2 - 6 } & $\mathrm{ke}-1\left(1^{\text {st }}\right)$ & $\mathrm{ke}-2\left(2^{\text {nd }}\right)$ & $\mathrm{ke}-3\left(3^{\text {rd }}\right)$ & $\mathrm{ke}-4\left(4^{\text {th }}\right)$ & $\mathrm{ke}-5\left(5^{\text {th }}\right)$ \\
\hline $90 \mathrm{~m} \times 90 \mathrm{~m}$ & 0,01 & 0,01 & 0,00 & 0,00 & 0,00 \\
$80 \mathrm{~m} \times 80 \mathrm{~m}$ & 0,00 & 0,01 & 0,00 & 0,00 & 0,01 \\
$70 \mathrm{~m} \times 70 \mathrm{~m}$ & 0,01 & 0,01 & 0,01 & 0,00 & 0,01 \\
$60 \mathrm{~m} \times 60 \mathrm{~m}$ & 0,07 & 0,03 & 0,01 & 0,03 & 0,01 \\
$50 \mathrm{~m} \times 50 \mathrm{~m}$ & 0,21 & 0,06 & 0,02 & 0,06 & 0,01 \\
$40 \mathrm{~m} \times 40 \mathrm{~m}$ & 0,40 & 0,12 & 0,02 & 0,04 & 0,06 \\
$30 \mathrm{~m} \times 30 \mathrm{~m}$ & 0,59 & 0,44 & 0,01 & 0,14 & 0,14 \\
$20 \mathrm{~m} \times 20 \mathrm{~m}$ & 1,01 & 1,53 & 0,04 & 0,24 & 0,36 \\
\hline
\end{tabular}

$\operatorname{Keterangan}($ Note $): \chi_{(0,95 ; 8)}^{2}=2,73$

Lampiran(Appendix) 7. Nilai $\chi^{2}$ hasil uji keseragaman luas bidang dasar tiap hektar dalam plot dibandingkan dengan luas bidang dasar dalam areal standar $100 \mathrm{~m}$ x $100 \mathrm{~m}$ (The $\chi^{2}$-values of homogenity test of basal area per hectare in plot compared with basal area in standard areas $100 \mathrm{~m} \times 100 \mathrm{~m}$ )

\begin{tabular}{|c|c|c|c|c|c|}
\hline \multirow{2}{*}{$\begin{array}{c}\text { Ukuran plot } \\
\text { (Plot size })\end{array}$} & \multicolumn{5}{|c|}{ Areal contoh (Sample area) $120 \mathrm{~m} \times 120 \mathrm{~m}$} \\
\cline { 2 - 6 } & $\mathrm{ke}-1\left(1^{\text {st }}\right)$ & $\mathrm{ke}-2\left(2^{\text {nd }}\right)$ & $\mathrm{ke}-3\left(3^{\text {rd }}\right)$ & $\mathrm{ke}-4\left(4^{\text {th }}\right)$ & $\mathrm{ke}-5\left(5^{\text {th }}\right)$ \\
\hline $90 \mathrm{~m} \times 90 \mathrm{~m}$ & 1,47 & 1,36 & 0,47 & 0,69 & 0,98 \\
$80 \mathrm{~m} \times 80 \mathrm{~m}$ & 0,86 & 0,40 & 0,86 & 0,26 & 0,18 \\
$70 \mathrm{~m} \times 70 \mathrm{~m}$ & 1,06 & 0,67 & 1,26 & 0,24 & 0,42 \\
$60 \mathrm{~m} \times 60 \mathrm{~m}$ & 0,24 & 1,13 & 1,33 & 0,79 & 0,86 \\
$50 \mathrm{~m} \times 50 \mathrm{~m}$ & 1,24 & 1,59 & 0,73 & 0,94 & 0,84 \\
$40 \mathrm{~m} \times 40 \mathrm{~m}$ & 0,86 & 2,14 & 1,09 & 0,62 & 0,73 \\
$30 \mathrm{~m} \times 30 \mathrm{~m}$ & 1,87 & 21,72 & 6,79 & 6,07 & 10,96 \\
$20 \mathrm{~m} \times 20 \mathrm{~m}$ & 348,71 & 873,81 & 363,48 & 290,69 & 223,82 \\
\hline
\end{tabular}

Keterangan (Note): $\chi_{(0.95: 8)}^{2}=2,73$ 